\title{
Effects of Supplementing Rumen-Protected Methionine on Production Performance, Apparent Digestibility, Blood Parameters, Ruminal Metabolites and Economic Effectiveness in Lactating Holstein Dairy Cows
}

Jialin Wei

China Agricultural University https://orcid.org/0000-0002-0072-5461

Mengying Dou

Henan University of Science and Technology

Shuai Liu

China Agricultural University

\section{Bichuan Yan}

Henan University of Science and Technology

Cuiyu Li

China Agricultural University

\section{Yinghui Zhang}

Evonik (China) Co., Ltd.

Jianxin Xiao ( $\nabla$ xiaojianxin-dairy@cau.edu.cn )

China Agricultural University https://orcid.org/0000-0002-3074-5973

\section{Yuanxiao Li}

Henan University of Science and Technology

\section{Research}

Keywords: Dairy cows, Rumen-protected methionine, Ruminal metabolites, Digestibility, Economic effectiveness

Posted Date: May 21st, 2021

DOI: https://doi.org/10.21203/rs.3.rs-526624/v1

License: (c) (1) This work is licensed under a Creative Commons Attribution 4.0 International License. Read Full License 


\section{Abstract}

Background: Because of disadvantages of excessive dietary crude protein (CP), decreasing dietary CP of dairy cows has attracted the worldwide attention. Rumen protected methionine (RPM) supplementation can allow lower $\mathrm{CP}$ diets and is beneficial to milk production performance, $\mathrm{N}$ efficiency of cows and environment. The aim of this study was to evaluate the effects of reducing dietary CP and supplementing RPM on production, digestibility of nutrients, blood parameters, ruminal metabolites and economic effectiveness in lactating Holstein dairy cows.

Results: A total of 96 lactating cows ( $63 \pm 25 \mathrm{~d}$ in milk; $34.4 \pm 5.74 \mathrm{~kg} / \mathrm{d}$ of milk production; mean \pm SD) were randomly assigned to 1 of 2 treatments: diet containing $17.3 \%$ CP without RPM (control group; CON; $\mathrm{n}=49$ ); diet containing $16.4 \% \mathrm{CP}$ with supplementing $15.0 \mathrm{~g} / \mathrm{d}$ of RPM (treatment group; RPM; $\mathrm{n}=47$ ). No effect was observed of reducing dietary CP on milk yield and milk composition. The apparent digestibility of nutrients was similar between treatments. The results related to blood showed that cows in RPM group exhibited lower concentration of blood urea nitrogen than that in CON group $(P<0.001)$. Moreover, there were no differences between treatments on concentrations of aspartate transaminase, alanine transaminase, alkaline phosphatase, globulin and albumin. In ruminal metabolites, microbial crude protein (MCP) of dairy cows in RPM group was higher compared with CON group $(P=0.006)$. Ruminal volatile fatty acid (VFA) contents were not changed by treatments except that the concentrations of butyrate and isovalerate of RPM group were higher than that of CON group at $2 \mathrm{~h}$ after feeding $(P<$ 0.05). In addition, supplying the diet of $16.4 \%$ CP with RPM supplementation to cows could reduce feeding cost by $0.5 \$ / \mathrm{d}$ per cow and boost net profits.

Conclusions: Lower dietary CP with RPM supplementation did not limit milk yield, milk composition and apparent digestibility of nutrients, and could improve nitrogen utilization of dairy cows and synthesis of MCP in rumen, change VFA production at $2 \mathrm{~h}$ after feeding, as well as boost the economic benefits of the dairy farms.

\section{Background}

To satisfy the protein requirement, cows sometimes are received excessive dietary crude protein (CP) and then excreted in the form of urea, which would be emitted into the atmosphere in the form of $\mathrm{NO}_{2}[1]$, or be hydrolyzed to $\mathrm{NH}_{3}$ and volatilized[2], ultimately harmful to the environment. In addition, some researchers noted high dietary $\mathrm{CP}$ has a negative impact on $\mathrm{N}$ utilization for dairy cows[3]. And there is no improvement in milk production and milk composition when dietary CP is increased up to 18\%[2] or $18.8 \%[4]$. Furthermore, $40 \%$ of feeding cost can be attributed to dietary protein[5], and excess protein in the diets will lead to high cost and reduce profit margins. In consideration of above-mentioned factors, decreasing dietary CP has attracted the attention from worldwide researchers. In fact, previous study has shown that ensuring ideal balance for AA, especially methionine (Met) and lysine (Lys) [2], is the key to formulate cow rations rather than for dietary protein[6]. 
Given that rumen undegradable protein (RUP) is significant to meet daily protein needs of cows especially during the lactation stage, an alternative strategy of feeding rumen-protected AA has been taken into consideration. Recently years, there have been some research that explored the effects of rumenprotected methionine (RPM) supplementation on dairy cows. Several studies indicated that RPM supplementation and decreasing dietary CP could increase milk production, milk protein, fat as well as lactose contents[7-10]. Recently research has shown that an increase in overall dry matter intake (DMI) could be found after parturition when cows fed lower dietary CP and RPM[11]. In addition, supplementing RPM may allow lower $\mathrm{CP}$ diets to improve $\mathrm{N}$ efficiency and reduce urinary $\mathrm{N}$ excretion[8, 12] and production of total gas and methane volume[13]. Meanwhile, a previous meta-analysis of dietary protein content noted that not overfeeding dietary $\mathrm{CP}$ is the most efficient means to increase efficiency of $\mathrm{N}$ utilization[14]. In general, reducing dietary CP levels with RPM supplementation would be beneficial to milk production performance and $\mathrm{N}$ efficiency of dairy cows, as well as environment. Other effects of RPM, especially in aspects of digestibility of nutrients, health, rumen function and farmer's profits need to be further explored.

Thus, the objective of the present study was to investigate the effects of reducing dietary CP levels and supplementing RPM on production performance, apparent digestibility of nutrients, blood parameters, ruminal metabolites and economic effectiveness in lactating Holstein dairy cows. We hypothesized that reducing dietary CP levels and supplementing RPM would not limit milk yield and composition, and could change rumen fermentation and farmer's profits.

\section{Materials And Methods}

\subsection{Treatments, Experimental Diet and Cows management}

This study was conducted at Shengsheng Dairy Farm in Luoyang City, Henan Province, China. Animal management and experimental procedures were approved by Animal Care Committee of China Agricultural University. A total of 96 lactating Holstein cows $(63 \pm 25 \mathrm{~d}$ in milk; $34.4 \pm 5.74 \mathrm{~kg} / \mathrm{d}$ of milk production; mean \pm SD) were randomly assigned to 1 of 2 dietary treatments. Experimental periods lasted $75 \mathrm{~d}$ and consisted of $15 \mathrm{~d}$ for diet adaptation and $60 \mathrm{~d}$ for data collection. Diets were fed as total mixed ration (TMR; Table 1): diet containing 17.3\% CP without RPM (control group; CON; $n=49$ ); diet containing $16.4 \% \mathrm{CP}$ with supplementing $15.0 \mathrm{~g} / \mathrm{d}$ of RPM (treatment group; RPM; $\mathrm{n}=47$ ). It is worth to mention that the diet of CON contains a Lys:Met ratio of 3.39:1, while that of treatment group was 2.84:1. The TMR were prepared by blending individual feed ingredients. All cows had free access to feed and water. 
Table 1

The feed ingredients and chemical composition in experimental diets ${ }^{1}$

\begin{tabular}{|lll|}
\hline Item & CON & RPM \\
\hline Feed ingredients(\% DM) & & \\
\hline Alfalfa & 11.3 & 11.3 \\
\hline Oat hay & 3.7 & 3.7 \\
\hline Corn silage & 45.2 & 44.9 \\
\hline Whole cottonseed & 2.5 & 5.0 \\
\hline Beet pulp & 2.5 & 2.5 \\
\hline Molasses & 3.5 & 3.5 \\
\hline Fat power & 0.5 & 0.5 \\
\hline Sodium bicarbonate & 0.4 & 0.4 \\
\hline Yeast & 0.5 & 0.5 \\
\hline Steam flaked maize & 1.3 & 3.7 \\
\hline Ground corn grain & 12.1 & 10.0 \\
\hline Wheat bran & 2.0 & 2.0 \\
\hline Corn gluten feed & 1.5 & 1.5 \\
\hline Distillers dried grains with soluble & 1.5 & 1.5 \\
\hline Vitamins and trace minerals & 1.6 & 1.6 \\
\hline Whole soybean & 0.8 & 0.8 \\
\hline Soybean meal & 9.0 & 6.2 \\
\hline Cotton expeller & - & 0.5 \\
\hline
\end{tabular}
${ }^{1}$ Treatments CON group and RPM group consists of total mixed ration containing 17.3 and $16.4 \% \mathrm{CP}$,
respectively.

${ }^{2}$ Rumen-protected Met product from Evonik (China) Co., Ltd.

${ }^{3} D M$ dry matter, $N E_{L}$ net energy for lactation, $C P$ crude protein, $N D F$ neutral detergent fiber, $A D F$ acid detergent fiber, peNDF physically effective neutral detergent fiber, NFC non-fiber carbohydrate, Met methionine, Lys lysine

${ }^{4}$ Estimated using the NRC (2001) model based on DM intakes

${ }^{5} \mathrm{NFC}=100(\% \mathrm{NDF}-\mathrm{NDIN} \times 6.25)-\% \mathrm{CP}-\%$ fat $-\%$ ash 


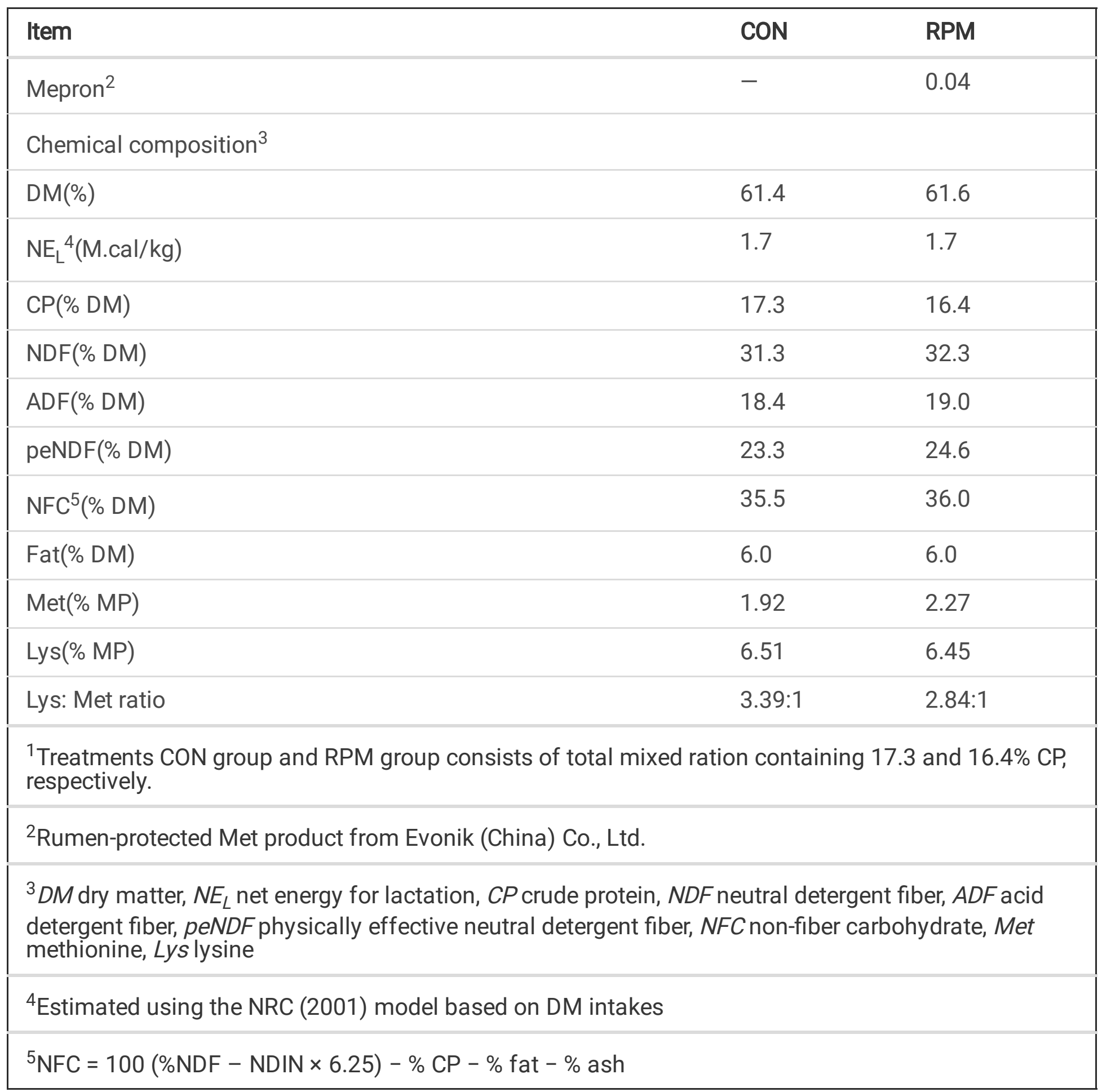

\subsection{Sample Collection and Analysis}

Cows were milked three times daily. Every 7 days in experimental period, milk was collected for analyzing for fat, true protein, lactose, milk urea nitrogen (MUN), somatic cell count (SCC), solids-not-fat (SNF), total solid (TS) and freezing point (FP) at the Luoyang Dairy Cow Center (Luoyang, China).

The experimental diets were fed as TMR three times daily. The amounts of feed offered was adjusted daily to 3 to $5 \%$ orts. The TMR samples were collected every 19 days to determine the composition. Samples dried at $65^{\circ} \mathrm{C}$ for $48 \mathrm{~h}$ until a constant weight was obtained. Then, feed composites were ground through a 1-mm screen (KRT-34; KunJie, Beijing, China) and analyzed for DM using method 950.15 of 
Association of Official Analytical Chemists[15]. Nitrogen was analyzed by the method $984.13[15]$ and crude protein (CP) was measured by multiplying 6.25 by the nitrogen content. Neutral detergent fiber (NDF) and acid detergent fiber (ADF) were measured according to the method described by Van Soest et al.[16]. Ash (method 942.05), calcium (Ca, method 965.09), and total phosphorus (P, method 965.17) were measured according to the AOAC[17].

On $\mathrm{d} 0, \mathrm{~d} 30, \mathrm{~d} 60$ of the experimental period, blood samples were randomly collected from the 15 cows of each group from tail vein of cows using $10 \mathrm{~mL}$ blood collection heparin-coated tubes (Vacutainer; aosaite Medical Instrument; Shandong) before morning feeding. Blood samples were immediately centrifuged at $3,500 \times \mathrm{g}$ at $4^{\circ} \mathrm{C}$ for $15 \mathrm{~min}$ to obtain plasma samples, which stored at $-20^{\circ} \mathrm{C}$ for further analysis. Concentrations of total protein (TP), albumin (ALB), Globulin (GLB), blood urea nitrogen (BUN), cholesterol (CHO), Aspartate transaminase (AST), Alanine transaminase (ALT), and Alkaline phosphatase (ALP) were measured by testing organization (People's Liberation Army 534 hospital, China).

Fecal samples were collected from 15 cows each group randomly and collected for 4 times $(0300,0800$, 1300 and 1800) each day on d $58, d 59$ and $d 60$. The fecal samples of each cow were evenly mixed to make a simple composite and taken to about $200 \mathrm{~g}$, adding $10 \%$ tartaric acid of $1 / 4$ fecal weight to fix nitrogen. These fecal grab samples were held at $65^{\circ} \mathrm{C}$ in a forced-air oven until completely dried, and were ground to pass a 1-mm screen (KRT-34; KunJie, Beijing, China). Fecal samples were analyzed for DM, NDF, ADF, CP, calcium, phosphorus, Ash as described earlier. The acid-insoluble ash (AIA) was used as an internal marker to determine the apparent digestibility of nutrients. TMR, orts and fecal samples were analyzed according to the procedure by Van Keulen and Young[18]. The apparent digestibility of nutrients was calculated as follows:

Apparent Digestibility of Nutrients $=[1-(\mathrm{Ad} \times \mathrm{Nf}) /(\mathrm{Af} \times \mathrm{Nd})] \times 100$.

where $A d=A I A$ in the diets $(\mathrm{g} / \mathrm{kg}) ; A f=A I A$ in the feces $(\mathrm{g} / \mathrm{kg}) ; \mathrm{Nd}=$ the concentration of a nutrient in the diet $(\mathrm{g} / \mathrm{kg}) ; \mathrm{Nf}=$ the concentration of a nutrient in the feces $(\mathrm{g} / \mathrm{kg})$.

On the last day of the experiment, 15 cows from each group were selected randomly and were collected samples of rumen fluid. Samples were collected before morning feeding and 2, 4, 6, 8, $12 \mathrm{~h}$ after morning feeding by oral sampler. Rumen fluid samples was filtered with four layers of gauze, centrifuged at 4000 $\mathrm{r} / \mathrm{min}$ for $15 \mathrm{~min}$ and took $1 \mathrm{~mL}$ supernatant, which was acidified with $4.5 \mathrm{~mL} 0.2 \mathrm{~mol} / \mathrm{L} \mathrm{HCL}$ for later analysis of ammonium nitrogen. Meanwhile, $4 \mathrm{~mL}$ supernatant was added $\mathrm{I} \mathrm{mL} 25 \%$ metaphosphate acid

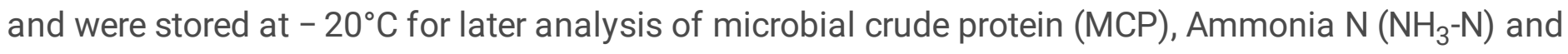
volatile fatty acid (VFA) including acetate, propionate, butyrate, valerate, isobutyrate and isovalerate (using Shimadzu GC-7A gas chromatograph, Japan).

\subsection{Statistical Analysis}

Dairy cow was used as the experimental unit, and all data were analyzed using SAS (SAS version 9.2, SAS Institute Inc., Cary, NC, USA). The milk yield, milk composition, apparent digestibility of nutrients, blood parameters, and ruminal metabolites were analyzed using PROC MIXED procedure of SAS. The 
milk yield, milk composition and blood parameters were calculated by averaging the three samples collected in $\mathrm{d} 0, \mathrm{~d} 30$ and $\mathrm{d} 60$ and then analyzed. The model of ruminal metabolites included the fixed effects of treatment, time, and time $\times$ treatment interaction, and cow within treatment as a random effect. Degrees of freedom were counted using the Kenward-Roger approximation option of the MIXED procedure. In order to explicate the repeated measures within-subject, the covariance structures were executed for each repeated variable on the basis of best fit determined by the Akaike information criterion. A significant difference between treatment group and control group was declared at $P<0.05$, tendencies were considered when $0.05 \leq P<0.10$, a highly significant difference indicated at $P \leq 0.01$.

\section{Results And Discussion}

\subsection{Milk Yield, and Milk Composition}

The results of the milk yield and milk composition are shown in Table 2. Milk yield and milk composition were not limited by the diet of lower protein with RPM supplementation. Meanwhile, SCC and MUN values for RPM diet decreased numerically and that of milk fat increased numerically. There was a trend for lower SNF with decreased CP feeding and RPM supplementation $(P=0.09)$. 
Table 2

Effects of adding Rumen-Protected methionine on milk yield, milk composition of dairy cows

\begin{tabular}{|c|c|c|c|c|}
\hline \multirow[t]{2}{*}{ Item $^{2}$} & \multicolumn{2}{|c|}{ Treatment $^{1}$} & \multirow[t]{2}{*}{ SEM } & \multirow[t]{2}{*}{$P$-value ${ }^{3}$} \\
\hline & CON & RPM & & \\
\hline Milk yield, kg/day & 36.8 & 36.8 & 0.07 & 1.00 \\
\hline $\mathrm{FP}\left({ }^{\circ} \mathrm{F}\right)$ & 31.0 & 40.0 & 0.94 & 0.40 \\
\hline SCC (cell/mL) & 153,100 & 115,900 & 0.42 & 0.38 \\
\hline \multicolumn{5}{|c|}{ Milk composition, \% } \\
\hline Fat & 3.49 & 3.80 & 0.03 & 0.24 \\
\hline Protein & 3.39 & 3.34 & 0.004 & 0.36 \\
\hline Lactose & 4.85 & 4.87 & 0.01 & 0.82 \\
\hline TS & 12.01 & 11.97 & 0.04 & 0.32 \\
\hline SNF & 8.59 & 8.41 & 0.01 & 0.09 \\
\hline MUN (mg/dL) & 15.44 & 14.82 & 0.07 & 0.35 \\
\hline \multicolumn{5}{|c|}{$\begin{array}{l}{ }^{1} \text { Treatments } \mathrm{CON} \text { group and RPM group consists of total mixed ration containing } 17.3 \text { and } 16.4 \% \mathrm{CP} \text {, } \\
\text { respectively }\end{array}$} \\
\hline \multicolumn{5}{|c|}{${ }^{2} F P$ freezing point, $S C C$ somatic cell count, $T S$ total solid, $S N F$ solids-not-fat, $M U N$ milk urea nitrogen } \\
\hline${ }^{3}$ Probability of a si & diet & & & \\
\hline
\end{tabular}

Our findings implied that decreasing dietary CP to $16.4 \%$ with RPM supplementation and relatively constant fermentable carbohydrate failed to have any negative effect on the milk yield and milk composition. The results are consistent with other researchers who found there were no changes in milk production performance when keeping the dietary AA balanced, and CP of the diets in these studies varied from 15.6-18\%[2], from 14.8-18.6\%[8], from 14.6-18.3\%[19], from 13-17\%[9]. Moreover, several trials have demonstrated that with RPM supplementation, milk yield[10, 20] and milk protein yield[21] increased. In contrast, a study reported that milk yield or milk composition like fat, lactose and SNF decreased significantly with diet of $11 \% \mathrm{CP}$, which may due to $11 \% \mathrm{CP}$ content was not enough to meet the milk production needs of dairy cows[9]. Furthermore, a report noted that compared with the diet of $17.3 \%$ CP, SNF yield in milk was lower in that of $16.1 \%$ CP[8], which was accorded with another study where reported that reduced dietary CP (from 17.1-15.8\%) could decrease milk SNF yield[22]. These studies indicated that lower dietary CP could result in less yield of milk SNF, which may account for the result of the current study.

In addition, no significant treatment effect was observed on MUN, while decreased with RPM group numerically in the current study. A previous study found that MUN concentration was lower when feeding 
the low-protein diet and supplementing rumen-protected essential amino acids[23]. A report elsewhere observed that compared with $18 \% \mathrm{CP}$ diet, the MUN values decreased with $16.4 \%$ and $15.6 \% \mathrm{CP}$ diets supplementing RPM[2]. However, some researchers noted that there was no significant change in MUN value if the dietary CP content changed by $1 \%[24]$. Therefore, the similar content of MUN in our study could be explained by that the difference in dietary CP between the two experimental groups was $0.9 \%$ (< 1\%). Hence, reduced MUN in RPM group may benefit to conception rates of dairy cows[25]. SCC level, an indicator of animal mammary disease, often increases when an infection of the mammary gland occurs $[26,27]$. In the current study, SCC values did not change and was numerically lower in RPM group. And in these two groups the SCC values were both within the normal levels $(100,000 \sim 314,000 \mathrm{cells} / \mathrm{mL})$ [28], which indicated the health condition of dairy cows may not be affected by treatments.

\subsection{Blood Parameters}

The effects of RPM supplementation on the blood parameters contents are shown in Table 3. The BUN value decreased $(P<0.001)$ with RPM supplementation. GLB was numerically higher in cows consuming lower protein diet supplemented RPM; however, this difference was not statistically significant. Other blood parameters did not exhibit any difference by treatment.

Table 3

Effects of adding Rumen-Protected methionine on the blood parameters of dairy cows

\begin{tabular}{|c|c|c|c|c|}
\hline \multirow[t]{2}{*}{ Item $^{2}$} & \multicolumn{2}{|c|}{ Treatment $^{1}$} & \multirow[t]{2}{*}{ SEM } & \multirow[t]{2}{*}{ P-value } \\
\hline & CON & RPM & & \\
\hline ALT (U/L) & 26.62 & 27.00 & 0.25 & 0.88 \\
\hline AST (U/L) & 88.38 & 99.00 & 0.99 & 0.28 \\
\hline $\mathrm{TP}(\mathrm{g} / \mathrm{L})$ & 73.74 & 74.20 & 0.14 & 0.75 \\
\hline $\operatorname{ALB}(\mathrm{g} / \mathrm{L})$ & 28.55 & 28.06 & 0.09 & 0.59 \\
\hline $\operatorname{GLB}(\mathrm{g} / \mathrm{L})$ & 45.19 & 46.13 & 0.18 & 0.61 \\
\hline ALB: GLB ratio & 0.64 & 0.62 & 0.004 & 0.49 \\
\hline BUN (mmol/L) & 5.30 & $4.14^{\mathrm{b}}$ & 0.03 & $<0.001$ \\
\hline $\mathrm{CHO}(\mathrm{mmol} / \mathrm{L})$ & 5.65 & 5.16 & 0.05 & 0.30 \\
\hline ALP (U/L) & 56.69 & 53.58 & 0.61 & 0.63 \\
\hline \multicolumn{5}{|c|}{$\begin{array}{l}{ }^{1} \text { Treatments } \mathrm{CON} \text { group and RPM group consists of total mixed ration containing } 17.3 \text { and } 16.4 \% \mathrm{CP} \text {, } \\
\text { respectively }\end{array}$} \\
\hline \multicolumn{5}{|c|}{$\begin{array}{l}{ }^{2} T P \text { total protein, } A L B \text { albumin, } G L B \text { globulin, } B U N \text { blood urea nitrogen, } C H O \text { cholesterol, } A S T \\
\text { aspartate transaminase, } A L T \text { alanine transaminase, } A L P \text { alkaline phosphatase }\end{array}$} \\
\hline
\end{tabular}


The significant decline of BUN in our findings accords with several earlier research. Bahrami-Yekdangi et al. conducted research in 2013, 2016 respectively. They found plasma urea concentrations were lower in cows consuming low-protein diets with RPM supplementation in 2013[2]. In another study, they also observed that BUN concentrations had a trend of a linear decline $(P=0.06)$ with reduced dietary $\mathrm{CP}$ and rumen degradable protein (RDP)[29]. These results may be explained by the fact that low-protein diets and ameliorating the balance of dietary AA, especially the ratio of Lys to Met, could enhance the protein utilization of dairy cows[23]. Moreover, it's worth to mention that some researchers indicated higher BUN may lead to saturation of transfer process because of the inhibitory effect of increased $\mathrm{NH}_{3}-\mathrm{N}$ contents in the rumen or a limitation of urease activity[30]. Reduced BUN concentrations might stimulate rumen urea transfer and increase urea transport rates[31]. Several research also noted the negative effect of high MUN or BUN value on reproductive performance of cows[32,33]. Therefore, these evidences indicate that reasonable BUN decline has a positive impact on the nitrogen utilization of dairy cows. A previous study supported that RPM supplementation could decrease inflammation of dairy cows, which may attribute to there is an association between RPM and galectin expression and secretion[34]. However, the findings from the abovementioned study differed from our results in that there was no difference in GLB contents, an indicator of immune system[35], between the two groups. We have no explanation for this result, and further experimentation may be required.

\subsection{Apparent digestibility of nutrients}

The results of the apparent digestibility of nutrients of dairy cows are shown in Table 4. The total apparent digestibility of DM, CP, NDF, ADF, ash, calcium and phosphorus were not affected by treatment diet, despite an overall reduction in lower dietary CP of $16.4 \%$. Furthermore, apparent minerals digestibility, calcium and phosphorus, were numerically higher in cows consuming lower protein diets; however, these differences were not statistically significant. 
Table 4

Effects of adding Rumen-Protected methionine on the apparent digestibility of nutrients of dairy cows

\begin{tabular}{|c|c|c|c|c|}
\hline \multirow[t]{2}{*}{ Item² (\%) } & \multicolumn{2}{|c|}{ Treatment $^{1}$} & \multirow[t]{2}{*}{ SEM } & \multirow[t]{2}{*}{ P-value ${ }^{3}$} \\
\hline & CON & RPM & & \\
\hline DM & 65.09 & 64.44 & 0.32 & 0.83 \\
\hline CP & 71.43 & 72.65 & 0.30 & 0.70 \\
\hline NDF & 48.60 & 41.35 & 0.51 & 0.13 \\
\hline ADF & 38.88 & 44.59 & 0.69 & 0.38 \\
\hline Ash & 53.43 & 55.17 & 0.34 & 0.59 \\
\hline Calcium & 42.75 & 44.24 & 0.51 & 0.76 \\
\hline Phosphorus & 45.96 & 48.50 & 0.65 & 0.68 \\
\hline \multicolumn{5}{|c|}{$\begin{array}{l}{ }^{1} \text { Treatments } \mathrm{CON} \text { group and RPM group consists of total mixed ration containing } 17.3 \text { and } 16.4 \% \mathrm{CF} \\
\text { respectively }\end{array}$} \\
\hline \multicolumn{5}{|c|}{${ }^{2} D M$ dry matter, $N E_{L}$ net energy for lactation, $C P$ crude protein, $N D F$ neutral detergent } \\
\hline \multicolumn{5}{|c|}{ fiber, $A D F$ acid detergent fiber, peNDF physically effective neutral detergent fiber } \\
\hline${ }^{3}$ Probability & ect of & & & \\
\hline
\end{tabular}

Some researchers mentioned that digestibility of OM, NDF, and ADF is associated to ruminal $\mathrm{NH}_{3}-\mathrm{N}_{\text {and }}$ $\mathrm{CP}$ contents of diets[8]. An earlier research observed lower ruminal organic matter (OM) digestion on the 9\% RDP diet, an insufficient level[36]. And inadequate RDP could result in a $\mathrm{NH}_{3}-\mathrm{N}$ deficiency in rumen, which could lower fiber digestion and harm microbial growth[37]. However, in our research, diets contained $16.4 \%$ or $17.3 \%$ CP with or without RPM supplementation did not have negative impacts on nutrients digestion, which also accords with some previous observations, where apparent digestibility of DM, OM, NDF, CP and starch were not different whether or not RPM was added, and digestibility of ADF would elevate by adding RPM[38, 39]. These above-mentioned results may be attributed to the sufficient dietary $\mathrm{CP}$ and rational ruminal $\mathrm{NH}_{3}-\mathrm{N}$ concentrations, which were above the minimum requirement $(\geq$ $5 \mathrm{mg} / \mathrm{dL}$ ) of ruminal $\mathrm{NH}_{3}-\mathrm{N}$ concentration for rumen microbial growth[40].

\subsection{Ruminal fermentation}

Effects of experimental diets on ruminal metabolites concentrations are shown in Table 5. The results showed that MCP in the RPM group was higher than that in CON group $(P=0.006)$. All ruminal metabolites contents were affected by time significantly $(P<0.05)$, but no differences were found between treatments. Treatment $\times$ time interaction effects $(P<0.05)$ were observed for ruminal butyrate and isovalerate concentrations, with cows fed RPM having higher butyrate and isovalerate contents at $2 \mathrm{~h}$ 
after feeding, as shown in Fig. 1. It is worth to mention that the mean content of $\mathrm{NH}_{3}-\mathrm{N}$ was numerically higher in treatment diet; however, the effect was not statistically significant.

Table 5

Effects of adding Rumen-Protected methionine on the Ruminal metabolites of dairy cows

\begin{tabular}{|c|c|c|c|c|c|c|}
\hline \multirow[t]{2}{*}{ Items ${ }^{2}$} & \multicolumn{2}{|c|}{ Treatment $^{1}$} & \multirow[t]{2}{*}{ SEM $^{3}$} & \multicolumn{3}{|l|}{$P$-value ${ }^{4}$} \\
\hline & CON & RPM & & Treatment & Time & Treatment $\times$ Time \\
\hline MCP & 116 & 135 & 5.33 & 0.01 & $<0.001$ & 0.56 \\
\hline Ammonia nitrogen $(\mathrm{mg} / \mathrm{dL})$ & 7.85 & 9.60 & 0.49 & 0.15 & 0.001 & 0.24 \\
\hline \multicolumn{7}{|l|}{ VFA (mmol/L) } \\
\hline Acetate & 38.55 & 40.48 & 1.67 & 0.62 & 0.002 & 0.11 \\
\hline Propionate & 19.38 & 19.99 & 1.22 & 0.78 & $<0.001$ & 0.09 \\
\hline Butyrate & 9.25 & 10.00 & 0.43 & 0.37 & $<0.001$ & 0.03 \\
\hline Valerate & 1.54 & 1.45 & 0.07 & 0.52 & 0.018 & 0.10 \\
\hline Isobutyrate & 1.03 & 1.06 & 0.07 & 0.82 & $<0.001$ & 0.74 \\
\hline Isovalerate & 1.84 & 1.66 & 0.09 & 0.28 & $<0.001$ & $<0.001$ \\
\hline Acetate:propionate ratio & 2.55 & 2.79 & 0.21 & 0.63 & 0.007 & 0.99 \\
\hline \multicolumn{7}{|c|}{$\begin{array}{l}{ }^{1} \text { Treatments } \mathrm{CON} \text { group and RPM group consists of total mixed ration containing } 17.3 \text { and } 16.4 \% \mathrm{CP} \text {, } \\
\text { respectively. }\end{array}$} \\
\hline \multicolumn{7}{|c|}{${ }^{2} M C P$ microbial crude protein, $V F A$ volatile fatty acid } \\
\hline \multicolumn{7}{|c|}{${ }^{3}$ Standard error of the least squares means } \\
\hline${ }^{4}$ Probability of a significant & ct of & & & & & \\
\hline
\end{tabular}

A previous study noted that with the development of RPM technology, most of protected Met is able to escape ruminal degradation, while a small proportion of Met is still released into the rumen and may alter the community composition of microbiota in rumen and their metabolism[11]. Several researchers have shown that unprotected methionine promoted ruminal bacteria growth rate and protein synthesis in vitro[41, 42]. And the study also found that rumen degradable methionine could increase the abundance of Selenomonas ruminantium[11], which is Gram-negative bacteria that could account for up to $51 \%$ of the ruminal total viable bacterial counts[43]. Some earlier scholars noted this strain was a typical ureolytic gastrointestinal tract anaerobe[44-46]. In the current study, we found that ruminal MCP content increased significantly in the PRM group $(P<0.01)$, which agreed with the increase of ruminal $\mathrm{NH}_{3}-\mathrm{N}$ concentration numerically, though. Based on the above-mentioned research, a possible explanation for our results might be that a small fraction of methionine RPM contained could be degraded in the rumen 
and then increase the bacteria populations in the rumen, of course. Therefore, more peptides and AA in the rumen were degraded to $\mathrm{NH}_{3}-\mathrm{N}$ via microbial deamination[41, 47] and then synthesize MCP better. The similar results were also observed in another study[13].

Although no effects were found in VFA concentration during the whole period, cows fed RPM had higher ruminal butyrate and isovalerate contents at $2 \mathrm{~h}$ after feeding, which is consistent with other studies [13, 48]. A previous research described that ruminal VFA production depended on substrates, bacterial populations and fiber degradation[49]. Some researchers noted that bacterial populations changed in fermenter fluid if rumen inoculum accepted different dietary CP with or without RPM in vitro, and abundance of Ruminococcus albus was the highest as dietary low protein with high RPM level[13]. In addition, another study started the diets which had well-balanced essential AA profiles especially RPM evaluated the abundance of ruminal fibrinolytic bacterial ( $R$. flavefaciens, F. succinogenes, and $R$. albus) [50]. Thus, we speculated the increase of ruminal butyrate and isovalerate contents at $2 \mathrm{~h}$ after feeding was because abundance of cellulolytic species changed in rumen when cows fed RPM and subsequently produced more VFA. However, a limitation of the current study is analysis of ruminal specific bacteria species was not included in the design.

\subsection{Feeding cost}

The price of TMR ingredients and the cost of feeding formulations are shown in Table 6. A previous study noted that the optimal levels of dietary RPM could boost the profits on dairy farm[51]. In the current study, the cost per $\mathrm{kg}$ of TMR was lower in RPM group, and the mean DMI of RPM group is $43.55 \mathrm{~kg} / \mathrm{d}$ per cow while that of CON group is $42.83 \mathrm{~kg} / \mathrm{d}$ per cow (not shown in the table). We calculated that decreasing dietary CP from 17.3-16.4\% with RPM supplementation could save about $0.5 \$ / d$ per cow in feeding cost (RPM vs. CON; 11.19 vs. 11.69 \$ d per cow). That meant, decreasing dietary CP from $17.3-16.4 \%$ with RPM supplementation can save about $\$ 180,000$ per year in a dairy herd of 1000 cows farm without limiting milk production performance. 
Table 6

The price of total mixed ration ingredients and the cost of feeding formulations

\begin{tabular}{|c|c|c|c|c|c|}
\hline \multirow[t]{2}{*}{ Ingredients } & & \multicolumn{4}{|l|}{ Treatment $^{1}$} \\
\hline & & CON & & RPM & \\
\hline Item & Price $(\$ / k g)$ & composition(kg) & $\operatorname{cost}(\$)$ & composition $(\mathrm{kg})$ & $\operatorname{cost}(\$)$ \\
\hline Alfalfa & 0.38 & 4.50 & 1.71 & 4.50 & 1.71 \\
\hline Oat hay & 0.25 & 1.50 & 0.38 & 1.50 & 0.38 \\
\hline Corn silage & 0.08 & 18.0 & 1.39 & 18.0 & 1.39 \\
\hline Whole cottonseed & 0.37 & 1.00 & 0.37 & 2.00 & 0.74 \\
\hline Beet pulp & 0.35 & 1.00 & 0.35 & 1.00 & 0.35 \\
\hline Molasses & 0.23 & 1.40 & 0.32 & 1.40 & 0.32 \\
\hline Fat power & 1.35 & 0.20 & 0.27 & 0.25 & 0.34 \\
\hline Sodium bicarbonate & 0.29 & 0.15 & 0.04 & 0.15 & 0.04 \\
\hline Yeast & 1.38 & 0.15 & 0.21 & 0.15 & 0.21 \\
\hline Steam flaked maize & 0.32 & 0.50 & 0.16 & 1.50 & 0.48 \\
\hline Ground corn grain & 0.02 & 5.00 & 0.10 & 4.00 & 0.08 \\
\hline Wheat bran & 0.01 & 0.80 & 0.01 & 0.80 & 0.01 \\
\hline Corn gluten feed & 0.01 & 0.60 & 0.01 & 0.60 & 0.01 \\
\hline $\begin{array}{l}\text { Distillers dried grains with } \\
\text { soluble }\end{array}$ & 0.03 & 0.60 & 0.02 & 0.60 & 0.02 \\
\hline $\begin{array}{l}\text { Mineral and Vitamin } \\
\text { premix }\end{array}$ & 0.04 & 0.65 & 0.02 & 0.65 & 0.02 \\
\hline Whole soybean & 0.04 & 0.30 & 0.01 & 0.30 & 0.01 \\
\hline Soybean meal & 1.54 & 3.60 & 5.54 & 2.50 & 3.85 \\
\hline Cotton expeller & 0.03 & 0.00 & 0.00 & 0.20 & 0.01 \\
\hline $\mathrm{RPM}^{2}$ & 21.5 & 0.00 & 0.00 & 0.02 & 0.32 \\
\hline Total cost & & 40.0 & 10.9 & 40.0 & 10.3 \\
\hline
\end{tabular}

\footnotetext{
${ }^{1}$ Treatments CON group and RPM group consists of total mixed ration containing 17.3 and $16.4 \% \mathrm{CP}$, respectively
}

${ }^{2} R P M$ rumen-protected methionine 


\begin{tabular}{|c|c|c|c|c|}
\hline \multirow[t]{2}{*}{ Ingredients } & \multicolumn{4}{|c|}{ Treatment $^{1}$} \\
\hline & CON & & RPN & \\
\hline Cost per kg & 1.0 & 0.273 & 1.0 & 0.257 \\
\hline \multicolumn{5}{|c|}{$\begin{array}{l}1 \text { Treatments CON group and RPM group consists of total mixed ration containing } 17.3 \text { and } 16.4 \% \mathrm{CP} \text {, } \\
\text { respectively }\end{array}$} \\
\hline
\end{tabular}

\section{Conclusion}

In this study, compared with $17.3 \%$ dietary $\mathrm{CP}$, milk yield and milk composition were not limited by the lower dietary CP (16.4\%) with RPM supplementation of $15.0 \mathrm{~g} / \mathrm{d}$ per cow. In fact, decreasing dietary CP from 17.3-16.4\% could reduce BUN concentration, which made a positive impact on the nitrogen utilization of dairy cows. In addition, higher ruminal MCP could be found in RPM group and concentrations of butyrate and isovalerate in the rumen of RPM group were higher than that of CON group at $2 \mathrm{~h}$ after feeding. In economic terms, supplying the diet of $16.4 \% \mathrm{CP}$ with RPM supplementation to cows could reduce feeding cost by $0.5 \$ / d$ per cow and boost net profits. In general, RPM may make a positive effect on dairy cows and several research programs are still needed to explore RPM more to discover its other vital roles in dairy cow life.

\section{Abbreviations}

DM: Dry matter; NEL: Net energy for lactation; CP: Crude protein; NDF: Neutral detergent fiber; ADF: Acid detergent fiber; peNDF: Physically effective neutral detergent fiber; NFC: Non-fiber carbohydrate; Met: Methionine; Lys: Lysine; FP: Freezing point; SCC: Somatic cell count; TS: Total solid; SNF: Solids-not-fat; MUN: Milk urea nitrogen; TP: Total protein; ALB: Albumin; GLB: Globulin; BUN: Blood urea nitrogen; CHO: Cholesterol; AST: Aspartate transaminase; ALT: Alanine transaminase; ALP: Alkaline phosphatase; MCP Microbial crude protein, VFA: Volatile fatty acid; TMR: Total mixed ration; RDP: Rumen degradable protein

\section{Declarations}

\section{Acknowledgements}

We thank the grants from Evonik Industries AG. We also acknowledge Shengsheng Dairy Farm (Luoyang, China) for assistance during the period of animal experiment. We gratefully acknowledge the help from the staff at China Agricultural University (Beijing, China) and Henan University of Science and Technology (Luoyang, China) for help in the laboratory testing and field sampling.

\section{Authors' contributions}


Conceived the idea and designed the experiments: ZJC and YHZ. Implemented the experiment: YXL.

Performed the analysis: JLW, BCY, MYD, CYL. Wrote the manuscript: JLW and SL. All authors read and approved the final manuscript.

\section{Funding}

This research was supported by grants from National Key Research and Development Program of China (2018YFD0501600), and supported by Evonik (China) Co., Ltd.

\section{Availability of data and material}

Not applicable.

\section{Ethics approval and consent to participate}

Not applicable.

\section{Consent for publication}

Not applicable.

\section{Competing interests}

The authors declare that they have no competing interests.

\section{Ethics approval and consent to participate}

Not applicable.

\section{References}

1. Marshall CJ, Beck MR, Garrett K, Barrell GK, Al-Marashdeh O, Gregorini P. Grazing dairy cows with low milk urea nitrogen breeding values excrete less urinary urea nitrogen. Sci Total Environ. 2020;739:139994.

2. Bahrami-Yekdangi $H$, Khorvash $M$, Ghorbani GR, Alikhani M, Jahanian R, Kamalian E. Effects of decreasing metabolizable protein and rumen-undegradable protein on milk production and composition and blood metabolites of Holstein dairy cows in early lactation. J Dairy Sci. 2014;97:3707-14.

3. Huhtanen P, Hristov AN. A meta-analysis of the effects of dietary protein concentration and degradability on milk protein yield and milk $\mathrm{N}$ efficiency in dairy cows. J Dairy Sci. 2009;92:3222-32.

4. Leonardi C, Stevenson M, Armentano LE. Effect of two levels of crude protein and methionine supplementation on performance of dairy cows. J Dairy Sci. 2003;86:4033-42. 
5. Liu E, VandeHaar MJ. Relationship of residual feed intake and protein efficiency in lactating cows fed high- or low-protein diets. J Dairy Sci. 2020;103:3177-90.

6. Broderick GA. Effects of varying dietary protein and energy levels on the production of lactating dairy cows. J Dairy Sci. 2003;86:1370-81.

7. Berthiaume R, Thivierge MC, Patton RA, Dubreuil P, Stevenson M, McBride BW, et al. Effect of ruminally protected methionine on splanchnic metabolism of amino acids in lactating dairy cows. $J$ Dairy Sci. 2006;89:1621-34.

8. Broderick GA, Stevenson MJ, Patton RA, Lobos NE, Olmos Colmenero JJ. Effect of supplementing rumen-protected methionine on production and nitrogen excretion in lactating dairy cows. J Dairy Sci. 2008;91:1092-102.

9. Nursoy H, Ronquillo MG, Faciola AP, Broderick GA. Lactation response to soybean meal and rumenprotected methionine supplementation of corn silage-based diets. J Dairy Sci. 2018;101:2084-95.

10. Schmidt J, Sipócz P, Cenkvári E, Sipócz J. Use of protected methionine (Mepron M 85) in cattle. Acta Vet Hung. 1999;47:409-18.

11. Abdelmegeid MK, Elolimy AA, Zhou Z, Lopreiato V, McCann JC, Loor JJ. Rumen-protected methionine during the peripartal period in dairy cows and its effects on abundance of major species of ruminal bacteria. Journal of animal science biotechnology. 2018;9:17.

12. Zhao Y, Rahman MS, Zhao G, Bao Y, Zhou K. Dietary supplementation of rumen-protected methionine decreases the nitrous oxide emissions of urine of beef cattle through decreasing urinary excretions of nitrogen and urea. J Sci Food Agric. 2020;100:1797-805.

13. Abbasi IHR, Abbasi F, Liu L, Bodinga BM, Abdel-Latif MA, Swelum AA, et al. Rumen-protected methionine a feed supplement to low dietary protein: effects on microbial population, gases production and fermentation characteristics. AMB Express. 2019;9:93.

14. Huhtanen P, Hristov AN. A meta-analysis of the effects of dietary protein concentration and degradability on milk protein yield and milk N efficiency in dairy cows. J Dairy Sci. 2009;92:3222-32.

15. AOAC. Official Methods of Analysis te, Association of Official Analytical Chemists. USA: Arlington V; 1990.

16. Van Soest PJ, Robertson JB, Lewis BA. Methods for dietary fiber, neutral detergent fiber, and nonstarch polysaccharides in relation to animal nutrition. J Dairy Sci. 1991;74:3583-97.

17. ed. AIOMoAt, AOAC International G, MD, 2000.

18. Vankeulen J, Young BA. EVALUATION OF ACID-INSOLUBLE ASH AS. A NATURAL MARKER IN RUMINANT DIGESTIBILITY STUDIES. J Anim Sci. 1977;44:282-7.

19. Castillo AR, Kebreab E, Beever DE, Barbi JH, Sutton JD, Kirby HC, et al. The effect of protein supplementation on nitrogen utilization in lactating dairy cows fed grass silage diets. J Anim Sci. 2001;79:247-53.

20. Patton RA. Effect of rumen-protected methionine on feed intake, milk production, true milk protein concentration, and true milk protein yield, and the factors that influence these effects: a meta- 
analysis. J Dairy Sci. 2010;93:2105-18.

21. Zanton GI, Bowman GR, Vázquez-Añón M, Rode LM. Meta-analysis of lactation performance in dairy cows receiving supplemental dietary methionine sources or postruminal infusion of methionine. $J$ Dairy Sci. 2014;97:7085-101.

22. Broderick GA, Stevenson MJ, Patton RA. Effect of dietary protein concentration and degradability on response to rumen-protected methionine in lactating dairy cows. J Dairy Sci. 2009;92:2719-28.

23. Arriola Apelo SI, Bell AL, Estes K, Ropelewski J, de Veth MJ, Hanigan MD. Effects of reduced dietary protein and supplemental rumen-protected essential amino acids on the nitrogen efficiency of dairy cows. J Dairy Sci. 2014;97:5688-99.

24. Flis SA, Wattiaux MA. Effects of parity and supply of rumen-degraded and undegraded protein on production and nitrogen balance in Holsteins. J Dairy Sci. 2005;88:2096-106.

25. Kananub S, Pechkerd P, VanLeeuwen J, Stryhn H, Arunvipas P. Evaluation of influence of milk urea nitrogen on reproductive performance in smallholder dairy farms. Aust Vet J. 2020;98:375-9.

26. Hernández-Ramos PA, Vivar-Quintana AM, Revilla I. Estimation of somatic cell count levels of hard cheeses using physicochemical composition and artificial neural networks. J Dairy Sci. 2019;102:1014-24.

27. Le Roux Y, Laurent F, Moussaoui F. Polymorphonuclear proteolytic activity and milk composition change. Vet Res. 2003;34:629-45.

28. Nasr MAF, El-Tarabany MS. Impact of three THI levels on somatic cell count, milk yield and composition of multiparous Holstein cows in a subtropical region. J Therm Biol. 2017;64:73-7.

29. Bahrami-Yekdangi M, Ghorbani GR, Khorvash M, Khan MA, Ghaffari MH. Reducing crude protein and rumen degradable protein with a constant concentration of rumen undegradable protein in the diet of dairy cows: Production performance, nutrient digestibility, nitrogen efficiency, and blood metabolites. J Anim Sci. 2016;94:718-25.

30. Harmeyer $\mathrm{J}$, Martens $\mathrm{H}$. Aspects of urea metabolism in ruminants with reference to the goat. J Dairy Sci. 1980;63:1707-28.

31. Muscher AS, Schröder B, Breves G, Huber K. Dietary nitrogen reduction enhances urea transport across goat rumen epithelium. J Anim Sci. 2010;88:3390-8.

32. Butler WR, Calaman JJ, Beam SW. Plasma and milk urea nitrogen in relation to pregnancy rate in lactating dairy cattle. J Anim Sci. 1996;74:858-65.

33. Ramirez-Valverde R, Misztal I, Bertrand JK. Comparison of threshold vs linear and animal vs sire models for predicting direct and maternal genetic effects on calving difficulty in beef cattle. $J$ Anim Sci. 2001;79:333-8.

34. Asiamah EK, Vailati-Riboni M, Zhou Z, Xu T, Loor JJ, Schimmel K, et al. Rumen-protected methionine supplementation during the peripartal period alters the expression of galectin genes associated with inflammation in peripheral neutrophils and secretion in plasma of Holstein cows. J Dairy Res. 2019;86:394-8. 
35. Chorfi Y, Lanevschi-Pietersma A, Girard V, Tremblay A. Evaluation of variation in serum globulin concentrations in dairy cattle. Vet Clin Pathol. 2004;33:122-7.

36. Stokes SR, Hoover WH, Miller TK, Blauweikel R. Ruminal digestion and microbial utilization of diets varying in type of carbohydrate and protein. J Dairy Sci. 1991;74:871-81.

37. Allen MS. Effects of diet on short-term regulation of feed intake by lactating dairy cattle. J Dairy Sci. 2000;83:1598-624.

38. Giallongo F, Hristov AN, Oh J, Frederick T, Weeks H, Werner J, et al. Effects of slow-release urea and rumen-protected methionine and histidine on performance of dairy cows. J Dairy Sci. 2015;98:3292308.

39. Lee C, Giallongo F, Hristov AN, Lapierre H, Cassidy TW, Heyler KS, et al. Effect of dietary protein level and rumen-protected amino acid supplementation on amino acid utilization for milk protein in lactating dairy cows. J Dairy Sci. 2015;98:1885-902.

40. Satter LD, Roffler RE. Nitrogen requirement and utilization in dairy cattle. J Dairy Sci. 1975;58:121937.

41. Gil LA, Shirley RL, Moore JE. Effect of methionine hydroxy analog on bacterial protein synthesis from urea and glucose, starch or cellulose by rumen microbes, in vitro. J Anim Sci. 1973;37:159-63.

42. Salsbury RL, Marvil DK, Woodmansee CW, Haenlein GF. Utilization of methionine and methionine hydroxy analog by rumen microorganisms in vitro. J Dairy Sci. 1971;54:390-6.

43. Caldwell DR, Bryant MP. Medium without rumen fluid for nonselective enumeration and isolation of rumen bacteria. Applied microbiology. 1966;14:794-801.

44. John A, Isaacson HR, Bryant MP. Isolation and characteristics of a ureolytic strain of Selenomonas ruminatium. J Dairy Sci. 1974;57:1003-14.

45. Smith CJ, Hespell RB, Bryant MP. Regulation of urease and ammonia assimilatory enzymes in Selenomonas ruminantium. Appl Environ Microbiol. 1981;42:89-96.

46. Wozny MA, Bryant MP, Holdeman LV, Moore WE. Urease assay and urease-producing species of anaerobes in the bovine rumen and human feces. Appl Environ Microbiol. 1977;33:1097-104.

47. Clark JH. Lactational responses to postruminal administration of proteins and amino acids. J Dairy Sci. 1975;58:1178-97.

48. Noftsger S, St-Pierre NR, Sylvester JT. Determination of rumen degradability and ruminal effects of three sources of methionine in lactating cows. J Dairy Sci. 2005;88:223-37.

49. Bannink A, Kogut J, Dijkstra J, France J, Kebreab E, Van Vuuren AM, et al. Estimation of the stoichiometry of volatile fatty acid production in the rumen of lactating cows. J Theor Biol. 2006;238:36-51.

50. Martin C, Mirande C, Morgavi DP, Forano E, Devillard E, Mosoni P. Methionine analogues HMB and $\mathrm{HMBi}$ increase the abundance of cellulolytic bacterial representatives in the rumen of cattle with no direct effects on fibre degradation. 182: ANIMAL FEED SCIENCE AND TECHNOLOGY; 2013. pp. 1624. 
51. Cho J, Overton TR, Schwab CG, Tauer LW. Determining the amount of rumen-protected methionine supplement that corresponds to the optimal levels of methionine in metabolizable protein for maximizing milk protein production and profit on dairy farms. J Dairy Sci. 2007;90:4908-16.

\section{Figures}
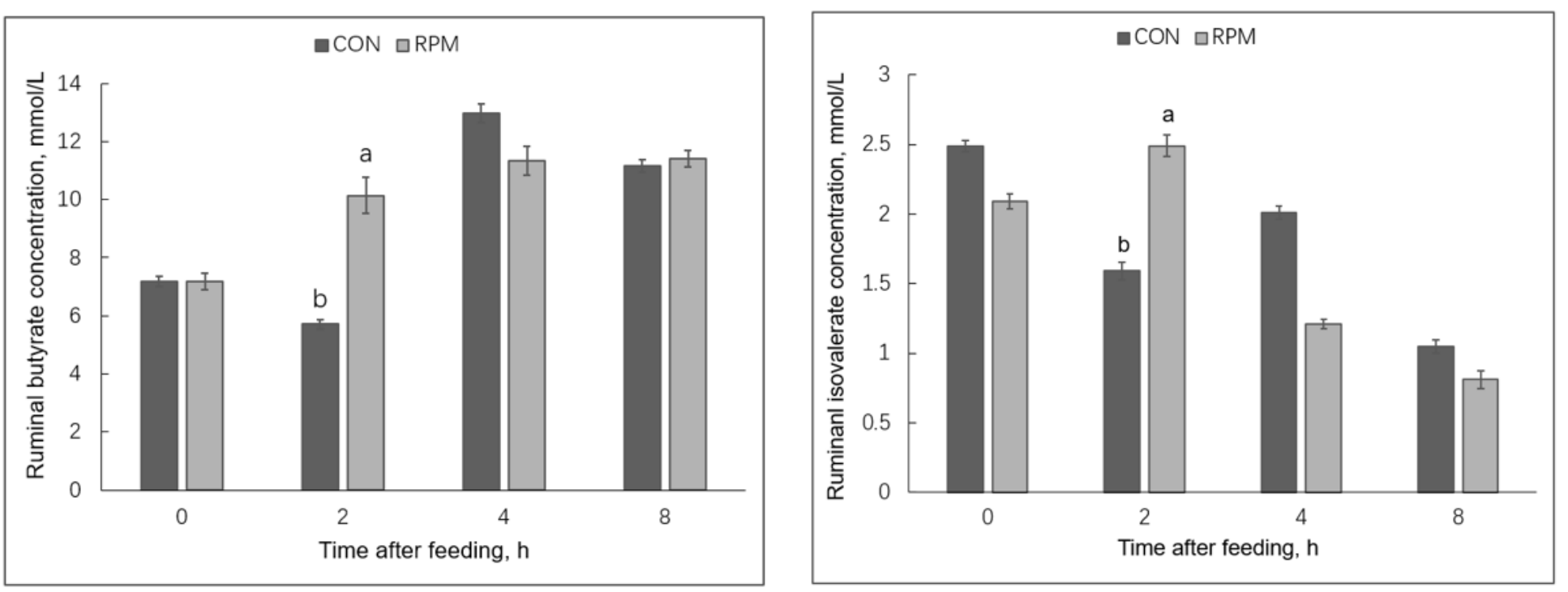

\section{Figure 1}

Ruminal butyrate and isovalerate concentrations in Holstein cows fed a control diet (CON) containing $17.3 \% \mathrm{CP}$ or treatment diet containing $16.4 \% \mathrm{CP}$ with RPM supplementation (RPM) at $0 \mathrm{~h}, 2 \mathrm{~h}, 4 \mathrm{~h}$ and $8 \mathrm{~h}$ after feeding. a,bLeast squares means within a row with different superscripts differ $(P<0.05)$. Bars indicate standard error of the means. 